\title{
Facial fractures: a 1-year retrospective study in a hospital in Belo Horizonte
}

\section{Fraturas de face: um estudo retrospectivo de 1 ano em um hospital de Belo Horizonte}

\author{
Bruno Ramos Chrcanovic* \\ Belini Freire-Maia** \\ Leandro Napier de Souza*** \\ Vasco de Oliveira Araújo**** \\ Mauro Henrique Nogueira Guimarães de Abreu ${ }^{* * * *}$
}

\begin{abstract}
A retrospective study was performed to assess facial fractures in patients treated at a public hospital in Belo Horizonte, in 2000. The data collected included age, gender, etiology, distribution of maxillofacial trauma considering day of the week and month, anatomic site of the fracture, and treatment. The analyses involved descriptive statistics and chi-squared test, Bonferroni test and analysis of variance. A total of 1,326 facial fractures were found in 911 patients. Most fractures occurred in adults with age ranging from 21 to 30 years. Men were more affected than women, with a male-female ratio of 4.69:1. Accidents causing facial fractures occurred predominantly on weekends. Bicycle and motorcycle accidents were the major cause of trauma, followed by interpersonal violence, automobile accidents, and falls. When the relation between the gender and the etiology of facial fractures was analyzed, a significant relation was noted between these variables $(p<0.001)$. There was also a relation between the patients' age and the site of the fractures $(p=0.0014)$. The mandible was found to be the most commonly fractured bone in the facial skeleton, followed by the zygomatic complex and the nose. A non-surgical approach was chosen in most cases. There were significant differences between the kind of treatment applied and the site of the fracture $(\mathrm{p}<0.001)$.
\end{abstract}

DESCRIPTORS: Maxillary fractures; Mandibular fractures; Facial injuries; Epidemiologic studies.

RESUMO: Um estudo retrospectivo foi realizado para avaliar fraturas faciais em pacientes atendidos no ano de 2000 em um hospital público de Belo Horizonte. As informações coletadas incluíam idade, sexo, etiologia, distribuição do trauma de acordo com o dia da semana e o mês, o local anatômico da fratura e o tratamento. As análises envolveram estatísticas descritivas, teste qui-quadrado, teste Bonferroni e análise de variância. Foram encontradas 1.326 fraturas de face em 911 pacientes. A maioria das fraturas ocorreu em adultos na faixa etária de 21 a 30 anos. Os homens foram mais acometidos do que as mulheres, numa proporção homem:mulher de 4,69:1. Os traumas causadores de fraturas faciais ocorreram predominantemente nos fins de semana. Os acidentes de moto e bicicleta foram a maior causa de trauma, seguidos por violência interpessoal, acidentes automobilísticos e quedas. Quando analisada a relação entre o gênero e a etiologia das fraturas de face, observou-se uma associação estatisticamente significativa entre essas variáveis $(\mathrm{p}<0,001)$. Houve também uma associação entre a idade dos pacientes e a localização das fraturas $(\mathrm{p}=0,0014)$. O osso facial mais fraturado foi a mandíbula, seguida por complexo zigomático e nariz. O tratamento conservador foi realizado na maioria dos casos. Houve diferenças estatisticamente significativas entre o tipo de tratamento instituído e a localização da fratura $(\mathrm{p}<0,001)$

DESCRITORES: Fraturas maxilares; Fraturas mandibulares; Traumatismos faciais; Estudos epidemiológicos.

\section{INTRODUCTION}

Maxillofacial fractures occur in a significant proportion of trauma patients. The epidemiology of facial fractures varies with the type, severity, and cause of injury depending on the population studied. The main causes of facial fractures are interpersonal violence and falls. The understanding of the cause, severity, and temporal distribution of maxillofacial trauma can aid in establishing clini-

\footnotetext{
*DDS; ${ }^{* * *}$ Chief of the Service of Oral and Maxillofacial Surgery - Maria Amélia Lins Hospital.

** MS in Oral and Maxillofacial Surgery, Pontifical Catholic University of Minas Gerais.

*** MS in Stomatology, Newton Paiva University Center.

$* * * * *$ PhD in Epidemiology, State University of Montes Claros.
} 
Chrcanovic BR, Freire-Maia B, Souza LN, Araújo VO, Abreu MHNG. Facial fractures: a 1-year retrospective study in a hospital in Belo Horizonte. Braz Oral Res 2004;18(4):322-8.

cal and research priorities for effective treatment and prevention of these injuries. In order to evaluate the types of facial fractures and their common etiology and treatment, this study was carried out including all patients with facial trauma at Maria Amélia Lins Hospital during 2000.

\section{MATERIALS AND METHODS}

The Oral and Maxillofacial Surgery Unit at Maria Amélia Lins Hospital is responsible for providing maxillofacial trauma coverage for the population from the metropolitan region of Belo Horizonte, Minas Gerais. A number of 4 million inhabitants are under coverage. This study is based on data belonging to those patients who suffered trauma from January 1 to December 31 of the year 2000, and were seen at Maria Amélia Lins Hospital. The data was collected from patients' medical charts. Age, gender, date of trauma, etiology of injury, anatomic site of fracture and treatment were the variables evaluated. The statistical analysis was performed using EpiInfo version $2002^{9}$, Microsoft Excel $^{\mathrm{TM}}$ software and SPSS version $11.0^{27}$. The analyses involved descriptive statistics and chisquared test, Bonferroni test and analysis of variance ${ }^{27}$. This study was approved by the Hospital Foundation of Minas Gerais (Fundação Hospitalar de Minas Gerais) ethical committee.

\section{RESULTS}

A total of 911 patients showed maxillofacial fractures at one or more facial bones in this study. The male-female distribution was $82.44 \%(\mathrm{n}=751)$ and $17.56 \%(\mathrm{n}=160)$, respectively. The majority of patients were male, with ages ranging from 21 to 30 years. The peak of incidence for women occurred in the age group from 31 to 40 years
(Table 1). The male-female ratio found was 4.69:1. The week distribution indicated Sunday as the day of the week with the greatest percentage of facial fractures $(24.26 \%)$, followed by Saturday (19.43\%) and Friday (13.28\%). The month distribution indicated October as the month with the greatest percentage of facial fractures. The biggest difference occurred between the months of September $(6.70 \%)$ and October (9.99\%).

The major cause of facial fractures was bicycle and motorcycle accidents $(23.05 \%)$, followed by interpersonal violence (21.30\%) (Table 2). Bicycle accidents, gunshots, sports, and motorcycle accidents were more prevalent among males; whereas the opposite occurred with interpersonal violence and falls. Analyzing the relation between gender and etiology of facial fractures, a significant relation was found between these variables ( $<<0.001$ ). Falls were more frequent in women than all other etiologies $(p<0.002)$, even though there were no significant differences when falls were compared with automobile accidents $(p=0.06)$ or interper-

TABLE 1 - Age distribution of patients with facial fractures.

\begin{tabular}{c|rr}
\hline \hline Age groups & \multicolumn{2}{|c}{$\%(\mathrm{n})$} \\
\hline $0-10$ & 6.15 & $(56)$ \\
\hline $11-20$ & 17.01 & $(155)$ \\
\hline $21-30$ & 33.15 & $(302)$ \\
\hline $31-40$ & 20.64 & $(188)$ \\
\hline $41-50$ & 13.50 & $(123)$ \\
\hline $51-60$ & 5.93 & $(54)$ \\
\hline $61-70$ & 1.76 & $(16)$ \\
\hline $71-80$ & 1.21 & $(11)$ \\
\hline $81-90$ & 0.65 & $(6)$ \\
\hline Total & 100.00 & $(911)$ \\
\hline \hline
\end{tabular}

TABLE 2 - Distribution of etiologic factors of facial fractures.

\begin{tabular}{l|rr|rrrr}
\hline \multicolumn{1}{|c|}{ Etiology } & \multicolumn{2}{|c|}{$\begin{array}{c}\text { Female } \\
\%(\mathrm{n})\end{array}$} & \multicolumn{2}{c|}{$\begin{array}{c}\text { Male } \\
\%(\mathrm{n})\end{array}$} & \multicolumn{2}{c}{$\begin{array}{c}\text { Total } \\
\%(\mathrm{n})\end{array}$} \\
\hline Bicycle and motorcycle accidents & 10.00 & $(21)$ & 90.00 & $(189)$ & 100.00 & $(210)$ \\
\hline Violence & 24.23 & $(47)$ & 75.77 & $(147)$ & 100.00 & $(194)$ \\
\hline Automobile accidents & 20.12 & $(34)$ & 79.88 & $(135)$ & 100.00 & $(169)$ \\
\hline Falls & 29.01 & $(47)$ & 70.99 & $(115)$ & 100.00 & $(162)$ \\
\hline Gunshots and white weapons & 8.62 & $(5)$ & 91.38 & $(53)$ & 100.00 & $(58)$ \\
\hline Others & 5.08 & $(6)$ & 94.92 & $(112)$ & 100.00 & $(118)$ \\
\hline Total & 17.56 & $(160)$ & 84.44 & $(751)$ & 100.00 & $(911)$ \\
\hline \hline
\end{tabular}


Chrcanovic BR, Freire-Maia B, Souza LN, Araújo VO, Abreu MHNG. Facial fractures: a 1-year retrospective study in a hospital in Belo Horizonte. Braz Oral Res 2004;18(4):322-8.

TABLE 3 - Type and localization of facial fractures.

\begin{tabular}{l|rr}
\hline \multicolumn{1}{c|}{ Site of fracture } & \multicolumn{2}{c}{$\%(\mathrm{n})$} \\
\hline Mandible total* & 39.97 & $(530)$ \\
\hline Coronoid process & 0.60 & $(8)$ \\
\hline Mandibular angle & 5.88 & $(78)$ \\
\hline Mandibular condyle & 12.75 & $(169)$ \\
\hline Mandibular body & 9.58 & $(127)$ \\
\hline Parasymphysis & 6.94 & $(92)$ \\
\hline Mandibular ramus & 0.90 & $(12)$ \\
\hline Symphysis & 3.32 & $(44)$ \\
\hline Zygomatic complex & 20.97 & $(278)$ \\
\hline Nose & 15.91 & $(211)$ \\
\hline Dento-alveolar & 6.41 & $(85)$ \\
\hline Zygomatic arch (isolated) & 5.96 & $(79)$ \\
\hline Le Fort type & 4.98 & $(66)$ \\
\hline Orbit & 2.49 & $(33)$ \\
\hline Frontal & 1.73 & $(23)$ \\
\hline Median maxilla suture & 0.75 & $(10)$ \\
\hline FNOE*** & 0.45 & $(6)$ \\
\hline Hard palate & 0.23 & $(3)$ \\
\hline Unknown** & 0.15 & $(2)$ \\
\hline Total & 00.00 & $(1,326)$ \\
\hline
\end{tabular}

* Sum of mandibular condyle, parasymphysis, angle, body, symphysis, coronoid process, and ramus. ${ }^{* *}$ Not recorded in the medical files. ${ }^{* * *}$ Fronto-naso-orbito-ethmoidal fracture.

sonal violence $(p=0.31)$. There was also a higher proportion of women with facial fractures caused by violence, but not significantly different when compared with facial fractures caused by automobile accidents $(p=0.35)$. There was a higher proportion of men $(94.92 \%)$ ( $p<0.001$ ) with fractures caused by other factors than fractures caused by automobile accidents (79.88\%).

There were a total of 1,326 facial fractures in 911 patients, with an average of 1.45 fractures per patient (1.47 in males and 1.36 in females). The most prevalent fractures were mandibular ones (39.97\%), followed by zygomatic complex fractures $(20.97 \%)$ and nose fractures (15.91\%) (Table 3). No surgical procedures were performed in 477 patients $(52.36 \%)$ (Table 4), whereas 430 patients underwent surgery (47.20\%). Sixty-nine surgical patients $(16.05 \%)$ were treated by means of intermaxillary fixation (IMF) with elastics and Erich bars; eight with Erich bars only (without IMF) (1.86\%); one hundred and sixteen (26.98\%) were treated with open reduction and internal fixation (ORIF) with ti- tanium miniplates, Erich bars and IMF; while 180 $(41.86 \%)$ were treated with ORIF only (Table 5). Information about one patient $(0.11 \%)$ concerning the type of treatment performed was not recorded in the chart. Three patients $(0.33 \%)$ were treated in another hospital.

There was an association between patients' age and the site of fractures $(p=0.0014)$. Analyzing which groups influenced such differences, it was observed that zygoma fractures occurred more frequently in older patients than mandible fractures $(\mathrm{p}<0.0167)$. The other comparisons did not show any significant differences (Table 6).

Table 7 shows significant differences between the kind of treatment applied and the fracture localization $(\mathrm{p}<0.001)$. There was a higher rate of surgical treatment of mandibular fractures when compared with zygoma fractures $(p<0.001)$ and nose fractures $(\mathrm{p}<0.001)$. There were no significant differences in surgical treatment comparing zygoma and nose fractures $(\mathrm{p}=0.335)$.

\section{DISCUSSION}

Continuous long-term collection of data regarding the epidemiology of maxillofacial fractures is important because it provides necessary information for the development and evaluation of preventive measures for reducing the incidence of facial injuries, such as the introduction of the seat belt legislation ${ }^{12,28}$. The nature of a retrospective study inherently results in flaws. These problems involve gaps in information and incomplete records. Furthermore, all data rely on the accuracy of the original examination and documentation. Some items may have been excluded in the initial examination or not recorded in the chart.

The results of epidemiological investigations vary depending on the demographics of the population studied. Factors such as geographic region, socioeconomic status, and temporal factors including period of the year and area can influence both the type and frequency of injuries in the population ${ }^{16}$. Applying multiple logistic regression analysis, Ribeiro et al. ${ }^{24}$ (2004) observed that maxillofacial fractures are not related to the employment status, but they are related to the education level.

The age distribution of patients with facial fractures in the present study corresponds to findings of other studies ${ }^{4,18,20,29}$. Young adults usually show greater physical activity, number of fights and self-mobility. The finding that the majority of 
Chrcanovic BR, Freire-Maia B, Souza LN, Araújo VO, Abreu MHNG. Facial fractures: a 1-year retrospective study in a hospital in Belo Horizonte. Braz Oral Res 2004;18(4):322-8.

TABLE 4 - Types of treatment performed in patients with facial fractures.

\begin{tabular}{l|rr}
\hline \multicolumn{1}{c|}{ Treatment } & \multicolumn{2}{|c}{$\%$ (n) } \\
\hline Non-surgical & 52.36 & $(477)$ \\
\hline Surgical & 47.20 & $(430)$ \\
\hline Treated in another hospital & $0.33 \quad(3)$ \\
\hline Unknown* & 0.11 & $(1)$ \\
\hline Total & $100.00 \quad(911)$ \\
\hline \hline
\end{tabular}

*Not recorded in the medical files.

TABLE 5 - Type of surgical treatment performed in patients with facial fractures.

\begin{tabular}{l|rr}
\hline \multicolumn{1}{c|}{ Treatment } & \multicolumn{2}{c}{$\%(\mathrm{n})$} \\
\hline ORIF** $^{*}$ & $41.86 \quad(180)$ \\
\hline Erich bars + IMF* + ORIF** & $26.98 \quad(116)$ \\
\hline Erich bars + IMF* & $16.05 \quad(69)$ \\
\hline $\mathrm{CR}^{* * *}$ & $11.86 \quad(51)$ \\
\hline Erich bars & $1.86 \quad(8)$ \\
\hline Erich bars + ORIF** & 1.39 & $(6)$ \\
\hline Total & 100.00 & $(430)$ \\
\hline \hline
\end{tabular}

*IMF $=$ intermaxillary fixation. ${ }^{* *}$ ORIF $=$ open reduction + internal fixation (titanium miniplates). ${ }^{* * *} \mathrm{CR}=$ closed reduction (in nose fractures).

TABLE 6 - Location of main fractures distributed by ages.

\begin{tabular}{l|c|c|c}
\hline \hline $\begin{array}{c}\text { Site of } \\
\text { fracture }\end{array}$ & Mean age & Variance & $\begin{array}{c}\text { Number of } \\
\text { cases }\end{array}$ \\
\hline Zygoma* & 34.26 & 172.72 & 357 \\
\hline Mandible & 30.99 & 180.39 & 530 \\
\hline Nose & 33.85 & 213.41 & 211 \\
\hline \hline
\end{tabular}

*Including zygomatic complex and zygomatic arch.

TABLE 7 - Type of treatment applied to the main fractures.

\begin{tabular}{l|r|r|r}
\hline \hline \multicolumn{1}{c|}{ Treatment } & Mandible & Zygoma* & \multicolumn{1}{c}{ Nose } \\
\hline Surgical & $\begin{array}{r}71.13 \\
(377)\end{array}$ & $\begin{array}{r}45.38 \\
(162)\end{array}$ & $\begin{array}{r}41.23 \\
(87)\end{array}$ \\
\% (n) & 28.87 & 54.62 & 58.77 \\
Conservative & $(153)$ & $(195)$ & $(124)$ \\
\% (n) & 100.00 & 100.00 & 100.00 \\
\hline Total & $(530)$ & $(357)$ & $(211)$ \\
$\%(n)$ &
\end{tabular}

${ }^{*}$ Including zygomatic complex and zygomatic arch. fractures is among males was similar to results of studies developed by Donaldson ${ }^{10}$ (1961) (4.49:1), Van Hoof et al. ${ }^{30}$ (1977) (5:1), Khalil, Shaladi ${ }^{20}$ (1981) (5.4:1), Scherer et al. ${ }^{25}$ (1989) (4.23:1), Bataineh $^{5}$ (1998) (3:1), Ugboko et al. ${ }^{29}$ (1998) (4.1:1), Hogg et al. ${ }^{18}$ (2000) (2.9:1), Fasola et al. ${ }^{12}$ (2003) (3.3:1), Ansari ${ }^{4}$ (2004) (3.84:1). This fact is probably due to a higher level of physical activity by men, and also because they are more involved in traffic accidents and fights.

This study shows a predominant distribution of accidents causing facial fractures on weekends. Such data is in accordance with the study of Lundin et al. ${ }^{21}$ (1973). These are days of great opportunity for outdoor and sports activities, short trips, recreation. Especially in Brazil, most soccer games occur on weekends, increasing the risk of violence among fans. Also, alcohol intake is greater on weekends. Facial fractures, especially those caused by violence, often happen under the influence of alcohol ${ }^{21,22}$.

The incidence of facial fractures showed no significant differences among the seasons of the year. In studies carried out in countries with distinct seasons (Summer, Autumn, Winter and Spring), a higher number of fractures in summer months could be expected. Olson et al. ${ }^{23}$ (1982), Andersson et al. ${ }^{3}$ (1984) and Hogg et al. ${ }^{18}$ (2000) showed in their studies that the majority of maxillofacial injuries occurred on weekends in summer months. These studies were carried out in the United States, Sweden and Canada, countries with distinct summer and winter seasons, as opposed to Brazil. In winter months, daylight diminishes and can cause visibility problems on the roadways ${ }^{18}$, including a significant amount of snowfall. This condition appears to result in less travel and greater caution. In summer months, there are good weather conditions and scheduled vacations, which provide greater opportunities for outdoor activities and travel ${ }^{23}$.

This study found bicycle and motorcycle accidents $(23.05 \%)$ as the main causes of facial fractures, followed by interpersonal violence $(21.30 \%)$, automobile accidents (18.55\%) and falls (17.78\%). There seems to be a trend toward assault as the most frequent cause of facial fractures in certain urban trauma centers, with facial fractures caused by motor vehicle accidents (MVA) occurring less often, as observed by some authors $\mathrm{s}^{4,6,8,24,26}$. In the present study, automobile and motorcycle/bicycle accidents were considered two distinct items, but if motor vehicle accidents (MVA) were considered 
Chrcanovic BR, Freire-Maia B, Souza LN, Araújo VO, Abreu MHNG. Facial fractures: a 1-year retrospective study in a hospital in Belo Horizonte. Braz Oral Res 2004;18(4):322-8.

(excluding only bicycle accidents), as in other studies $^{4,12,18,25,28}$, they would represent $25.68 \%$ of all causes of facial fractures, becoming the principal etiology. Despite the increased use and design of protective devices for motor vehicle occupants, MVA is still the leading cause of injury. Young people are most often involved in interpersonal violence and sports injuries, while falling accidents predominate in older age groups. Women were relatively more affected by violence than men (see Table 2). Maxillofacial trauma in women victims of domestic violence and rape is not simply a surgical problem, but a social one as well ${ }^{13}$. Unlike facial fractures and injuries caused by motor vehicle accidents, which are random events, injuries caused by domestic violence or rape quite frequently involve women from poorer socioeconomic backgrounds, who may be unwilling or unable to leave their home situations.

Many studies have shown MVA as the primary cause of maxillofacial fractures ${ }^{1,4,5,11,12,15,20,29-31}$. Ajagbe et al. ${ }^{2}$ (1977) states that MVA occur largely because of recklessness and negligence of the driver, poor maintenance of vehicles, often driving under the influence of alcohol or drugs and complete disregard of traffic laws. Because of legislative changes and preventive measures involving seat belt and airbag use, as well as the reduction of drinking and driving, MVA-related facial injuries have decreased in some developed countries, and interpersonal violence has emerged as the predominant cause of facial trauma, with alcohol and unemployment as contributing factors ${ }^{5,16,18,28}$. Hogg et al. ${ }^{18}$ (2000) demonstrated that occupants of vehicles who are not wearing seat belts are injured in crashes at a rate more than five times higher than that of occupants wearing a seat belt. They also demonstrated that the odds of maxillofacial injury drop to nearly half with the use of an airbag.

The mandible was the most prevalent facial bone fractured, followed by the zygomatic complex and the nose. The mandible is one of the most frequent targets in fights and also a frequently fractured bone in MVA. Down et al. ${ }^{11}$ (1995) have found MVA to be the most common cause of maxillofacial injury in patients that have serious or multiple injuries. Considering that the present study assessed the patients attended at a unit of Oral and Maxillofacial Surgery, fewer cases of nose fractures could be expected, if compared to other reports in the related literature ${ }^{19,21}$, since the Plastic Surgery service might have treated most cases of nose fractures in our hospital.
In our institution, rigid internal fixation is routinely used with titanium plates and screws for treating facial fractures, following a worldwide trend. In spite of that, it seems that conservative methods may still provide acceptable results ${ }^{17}$. Metal arch bars secured with soft stainless wires (Erich bars) are generally used for immobilization of comminuted mandibular and condylar fractures in our service. Condylar fractures with open reduction in cases of condylar displacement into the middle cranial fossa, condylar displacement to the external auditory canal, impossibility to obtain an adequate occlusion by non-surgical treatment, and open joint wounds with the presence of foreign body or gross contamination are treated at our service according to the recommendations of Betts ${ }^{7}$ (1999). We open reduce condylar fractures in some cases when there are associated comminuted midface fractures, bilateral fractures in edentulous jaws when splinting of the arches is not possible, and medical conditions that need immediate jaw function, according to Zide, Kent ${ }^{32}$ (1983). There were 116 cases which were treated with Erich bars and intermaxillar fixation, combined with internal fixation with titanium miniplates and screws. We do not always fix different mandibular fractures in the same patient with miniplates; in these cases, intermaxillar fixation is also used. We believe that there is no need to use internal fixation in every mandibular fracture and that using this combination of treatment (IMF + ORIF) we are searching for a more "conservative treatment", since some sites of fractures in the same patient can be treated with close reduction.

Several methods of prevention may serve to reduce the risk and to minimize complications resulting from automobile accidents, one of the predominant causes of injury among the population. There are some proposals to reduce traffic accidents: more adequate protection for both driver and passenger (increased seat belt and air bag use in cars); lower speed limits; better highway design; greater use of driver education programs; and more rigid requirements for license renewal, including thorough eye and medical examinations ${ }^{14,25}$.

Violence prevention programs focusing on both assault and self-inflicted injury may help decrease the maxillofacial trauma resulting from intentional injuries among the population. Hogg et al. ${ }^{18}$ (2000) stated that in addition to the current drinking and driving campaigns, specific control of alcohol use is needed for both MVA and violence prevention programs, because more than $80 \%$ of the alcohol- 
Chrcanovic BR, Freire-Maia B, Souza LN, Araújo VO, Abreu MHNG. Facial fractures: a 1-year retrospective study in a hospital in Belo Horizonte. Braz Oral Res 2004;18(4):322-8.

related injuries involved these two mechanisms in their study.

Further studies including facial fractures are always necessary, because the trends in the etiology of maxillofacial trauma are always changing, and the etiology of fractures may suggest new ways to prevent these injuries.

\section{CONCLUSIONS}

1. Facial fractures occur primarily among men under 30 years of age in the population studied.

2. There are more accidents causing facial fractures on weekends.

3. The most common causes of facial fractures in this study were bicycle and motorcycle ac-

\section{REFERENCES}

1. Adekeye EO. The pattern of fractures of the facial skeleton in Kaduna, Nigeria. A survey of 1,447 cases. Oral Surg Oral Med Oral Pathol 1980;49(6):491-5.

2. Ajagbe HÁ, Daramola JO, Oluwasanmi JO. Civilian-type facial injuries. A retrospective study of cases seen at the University College Hospital, Ibadan, Nigeria. Niger Med J 1977;7:432-6.

3. Andersson L, Hultin M, Nordenram A, Ramstrom G. Jaw fractures in the county of Stockholm (1978-1980) (I). General survey. Int J Oral Surg 1984;13(3):194-9.

4. Ansari MH. Maxillofacial fractures in Hamedan province, Iran: a retrospective study (1987-2001). J Craniomaxillofac Surg 2004;32(1):28-34.

5. Bataineh AB. Etiology and incidence of maxillofacial fractures in the north of Jordan. Oral Surg Oral Med Oral Pathol Oral Radiol Endod 1998;86(1):31-5.

6. Beaumont E, Lowrie JF, Cleaton-Jones FE. An analysis of fractures of the facial skeleton in three populations in the Johannesburg urban area. J Dent Assoc S Afr 1985;40(11):633-8

7. Betts NJ. Discussion of the article: endoscope-assisted fixation of mandibular condylar process fractures (Lauer G, Schmelzeisen R). J Oral Maxillofac Surg 1999;57:39-40.

8. Brook IM, Wood N. Aetiology and incidence of facial fractures in adults. Int J Oral Surg 1983;12(5):293-8.

9. Dean AG, Arner TG. Epi-Info: a word-processing, data base and statistic program for public health on IBM-compatible microcomputers. Atlanta: Centers of Disease Control and Prevention; 2002.

10. Donaldson KI. Fractures in the facial skeleton: a survey of 255 patients. NZ Dent J 1961;57:55-64.

11. Down KE, Boot DA, Gorman DF. Maxillofacial and associated injuries in severely traumatized patients: implications of a regional survey. Int J Oral Maxillofac Surg 1995;24(6):409-12.

12. Fasola AO, Nyako EA, Obiechina AE, Arotiba JT. Trends in the characteristics of maxillofacial fractures in Nigeria. J Oral Maxillofac Surg 2003;61(10):1140-3. cidents, interpersonal violence, automobile accidents, and falls; if we consider automobile, bicycle and motorcycle accidents as "motor vehicle accidents", this last category appears as the major cause of facial fractures.

4. Overall, the most common sites of fracture in the face are the mandible, zygomatic complex and nose.

5. The condyle is the most common site of fractures of the mandible.

6. The number of patients with facial fractures undergoing surgical treatment was almost equal to the number of patients undergoing conservative treatment.

7. Open reduction and internal fixation with miniplates is a common treatment in our institution nowadays.

13. Fisher EB, Kraus H, Lewis VL. Assaulted women: maxillofacial injuries in rape and domestic violence. Plast Reconstr Surg 1990;86(1):161-2.

14. Goldschmidt MJ, Castiglione CL, Assael LA, Litt MD. Craniomaxillofacial trauma in the elderly. J Oral Maxillofac Surg 1995;53(10):1145-9.

15. Hagan EH, Huelke DF. An analysis of 319 case reports of mandibular fractures. J Oral Surg Anest Hosp Dent Serv 1961;19:93-104.

16. Haug RH, Prather J, Indressano T. An epidemiologic survey of facial fractures and concomitant injuries. J Oral Maxillofac Surg 1990;48:926-32.

17. Hidding J, Wolf R, Pingel D: Surgical versus non-surgical treatment of fractures of the articular process of the mandible. J Craniomaxillofac Surg 1992;20(8):345-53.

18. Hogg NJV, Stewart TC, Armstrong JE, Girotti MJ. Epidemiology of maxillofacial injuries at trauma hospitals in Ontario, Canada, between 1992 and 1997. J Trauma 2000;49(3):425-32.

19. Kaban LB, Mulliken JB, Murray JE. Facial fractures in children: an analysis of 122 fractures in 109 patients. Plast Reconstr Surg 1977;59:15-20.

20. Khalil AF, Shaladi OA. Fractures of the facial bones in the eastern region of Libya. Br J Oral Surg 1981;19(4):300-4.

21. Lundin K, Ridell A, Sandberg N, Ohman A. One thousand maxillo-facial and related fractures at the ENT-clinic in Gothenburg. A two-year prospective study. Acta Otolaryngol 1973;75(4):359-61.

22. Oikarinen K, Kauppi H, Altonen M, Laitakari K. Causes and types of mandibular fractures in northern Finland in 1980-1986. Proc Finn Dent Soc 1988;84(4):227-33.

23. Olson RA, Fonseca RJ, Zeitler DL, Osbon DB. Fractures of the mandible: a review of 580 cases. J Oral Maxillofac Surg 1982;40(1):23-8.

24. Ribeiro MF, Marcenes W, Croucher R, Sheiham A. The prevalence and causes of maxillofacial fractures in patients attending accident and emergency departments in Recife-Brazil. Int Dent J 2004;54(1):47-51. 
Chrcanovic BR, Freire-Maia B, Souza LN, Araújo VO, Abreu MHNG. Facial fractures: a 1-year retrospective study in a hospital in Belo Horizonte. Braz Oral Res 2004;18(4):322-8.

25. Scherer M, Sullivan WG, Smith DJ, Phillips LG, Robson MC. An analysis of 1,423 facial fractures in 788 patients at an urban trauma center. J Trauma 1989;29(3):388-90.

26. Starkhammer H, Olofsson J. Facial fractures: a review of 922 cases with special reference to incidence and aetiology. Clin Otolaryngol 1982;7(6):405-9.

27. Statistical Package for Social Sciences - SPSS 11.0 for Windows. New York: Claritas Incorporation; 2001.

28. Telfer MR, Jones GM, Shepherd JP. Trends in the aetiology of maxillofacial fractures in the United Kingdom (1977-1987). Br J Oral Maxillofac Surg 1991;29(4):250-5.

29. Ugboko VI, Odusanya AS, Fagade OO. Maxillofacial fractures in a semi-urban Nigerian teaching hospi- tal. A review of 442 cases. Int J Oral Maxillofac Surg 1998;27(4):286-9.

30. van Hoof RF, Merkx CA, Stekelenburg EC. The different patterns of fractures of the facial skeleton in four European countries. Int J Oral Surg 1977;6(1):3-11.

31. Zachariades N, Papavassiliou D, Papademetroiu I, Koundouris I. Fractures of the facial skeleton in Greece. A retrospective study covering 1791 cases in 10 years. J Maxillofac Surg 1983;11(3):142-4.

32. Zide MF, Kent JN. Indications for open reduction of mandibular condyle fractures. J Oral Maxillofac Surg 1983; 41(2):89-98.

Received for publication on Feb 05, 2004

Sent for alterations on Aug 16, 2004 Accepted for publication on Sep 29, 2004 